DOI: https://doi.org/10.35387/ucj.1(3).2021.51-57

\title{
OKSANA TOVKANETS
}

\section{INTERNATIONAL STRATEGIES IN MODERNIZATION TRAINING OF EDUCATIONAL MANAGEMENT SPECIALISTS IN THE EUROPEAN HIGHER EDUCATION SYSTEM}

\begin{abstract}
The article analyzes the impact of international strategies for modernization of education on the content of training specialists in educational management in the European higher education system. The purpose of the article is to substantiate the influence of international strategies for the modernization of education on the content of training specialists in educational management in the European system of higher education. The research was carried out on the basis of methods of theoretical generalization; comparative analysis; methods of grouping and systematization. It is revealed that in modern conditions, among the factors of development of European higher education, three important ones are substantiated, which are directly related to the development of the educational space: smart growth: development of the economy based on knowledge and innovation; sustainable growth: creating an economy based on the rational use of resources, ecology and competition; inclusive growth: promoting employment, social and territorial consensus. The strategic goal of the national policy of the EU in the field of education at the beginning of the XXI century there are problems of purposeful influence on the conditions and preconditions for the implementation of the rules of law, focusing on the benefits of modernization of educational activities in the period of transformation, improvement of the entire education system and the mechanism of realization of the constitutional right to education. The areas that have the greatest impact on the process of training specialists in education management in European education are identified: focus on methodological support of activities within European education; standardization of educational content, licensing, certification and accreditation of educational institutions, recognition of qualifications at the level of higher education; improving the education management system, decentralization and diversification in education. It is emphasized that the development of human capital is at the heart of the global development strategy.
\end{abstract}

Key words: professional training, content of training, development strategies, European higher education.

\section{МІЖНАРОДНІ СТРАТЕГІЇ У МОДЕРНІЗАЦІЇ ПІДГОТОВКИ СПЕЦІАЛІСТІВ З УПРАВЛІННЯ ОСВІТОЮ В ЄВРОПЕЙСЬКІЙ СИСТЕМІ ВИЩОЇ ОСВІТИ}

Анотація. У статті аналізується вплив міжнародних стратегій модернізації освіти на зміст підготовки фахівців з менеджменту освіти в європейській системі вищої освіти. Метою статті є обгрунтування впливу міжнародних стратегій модернізації освіти на зміст підготовки фахівців з менеджменту освіти в європейській системі вищої освіти. Дослідження проводилось на основі методів теоретичного узагальнення; порівняльного аналізу; методів групування та систематизації. Виявлено, що в сучасних умовах серед факторів розвитку європейської вищої освіти обгрунтовано три важливі, які безпосередньо пов'язані з розвитком освітнього простору: розумне зростання: розвиток економіки на основі про знання та інновацї; стійке зростання: створення економіки на основі раціонального використання ресурсів, екології та конкуренції; інклюзивне зростання: сприяння зайнятості, соціальному та територіальному консенсусу. Стратегічною метою національної політики ЄС у сфері освіти на початку ХХІ століття є проблеми цілеспрямованого впливу на умови та передумови реалізації норм права, увага яких акцентується на перевагах модернізації освітньої діяльності в період трансформації, удосконалення всієї системи освіти та механізму реалізації конституційного права на освіту. Визначено напрями, які мають найбільший вплив на процес підготовки фахівців з управління освітою в європейській освіті: орієнтація на методичне забезпечення діяльності в рамках європейської освіти; стандартизація змісту освіти, ліцензування, атестація та акредитація навчальних закладів, визнання кваліфікацій за рівнем вищої освіти; удосконалення системи управління освітою, децентралізація та диверсифікація освіти. Наголошується, що в основі глобальної стратегії розвитку лежить розвиток людського капіталу.

Ключові слова: професійна підготовка, зміст навчання, стратегії розвитку, європейська вища освіта.

Introduction. The formation of the European educational space is a reflection of global integration processes, which has acquired a strategic direction of the EU's activities aimed 
at transforming Europe into a region with high-quality education. Ukrainian society has consciously chosen the course of European integration, which necessitates intensive changes in the political, economic and social life of our country, and most importantly - requires active reforms in the domestic education sector, aimed at achieving the best world standards.

The aim of the study is to substantiate the influence of international strategies for modernization of education on the content of training specialists in educational management in the European system of higher education.

Theoretical basis and methods of research. Domestic and foreign researchers addressed the problems of education development and its legislative support, considering it from various aspects, in particular: philosophical (V. Andrushchenko, L. Bell, V. Geets, M. Zgurovsky, V. Kremen, G. Stevenson and others), public administration (D. Petrova, M. Pankova and others), pedagogical (G. Yelnikova, L. Lukyanova, A. Luk, N. Nychkalo, V. Oliynyk, Ya. Prukha, L. Pukhovska, A. Saiti, T. Sorochan, D. Hogan and others). In the process of writing the article methods of theoretical generalization and analysis were used; comparative analysis; methods of grouping and systematization, which allowed to justify the influence of international strategies for modernization of education on the content of training specialists in educational management in the European system of higher education.

Results. Defining development tasks and priorities is a complex planning process that helps to set goals of activity, strategic directions, tasks and tools to ensure their implementation.

In order to define the strategic objectives of training specialists in education management, we turned to the main strategic documents that are directive in defining the goals and directions of modernization of education in European higher education.

International organizations paid great attention to the problem of the development of education in the European context. In March 2010, the European Commission adopted a strategy for economic development for the next 10 years - «Europe 2020: a strategy for smart, sustainable and inclusive growth» (hereinafter - the Strategy «Europe 2020»), which orients European society to a new type of humanistically innovative education, its specificity in the world and economic spaces, educating a generation of young people who will be protected and mobile in the labor market. It should be noted that the European Economic Development Strategy «Europe 2020» identified five strategic goals of EU development for this period: increasing employment; development of scientific and research developments; the problem of climate change/energy; raising the level of education; overcoming poverty and social isolation.

Among the many factors strengthening the economy are three important ones that are directly related to the development of educational space:

- smart growth: development of an economy based on knowledge and innovation;

- sustainable growth: creating an economy based on the appropriate use of resources, ecology and competition;

- Inclusive growth: promoting employment, social and territorial consensus.

In this regard, the following main goals have been set: $75 \%$ of the population aged 20 to 64 should be employed; $3 \%$ of the EU's gross domestic product should be invested in research; at least $40 \%$ of young people must have higher education; reducing the number of people at risk of falling below the poverty line (Europe 2020. Strategy for smart, sustainable and inclusive growth).

In order to enable the adaptation of the Europe 2020 Strategy to its specific situation, the European Commission invites states to transform EU objectives into their national strategies. The goals capture the essence of smart, sustainable and inclusive growth, but they are not exhaustive. The EU sets itself a significant number of tasks for the implementation of the Europe 2020 Strategy.

Attention should be paid to areas that can be a guideline for the content of educational programs in the training of specialists in education management.

For the effective development and achievement of the set goals of the EU, seven priority areas of activity have been identified: «Innovation Union», «Youth Movement», «Development of digital technologies in Europe», "Appropriate use of resources in Europe», «Industrial policy aimed at globalization», «Development of new skills and jobs», «European policy against poverty» (Europe 2020. Strategy for smart, sustainable and inclusive growth). 
In the context of our research, the factor «Smart growth: an economy based on knowledge and innovation» is relevant, in which it is determined that the smart growth of the EU means strengthening the interaction of scientific knowledge, research and innovation with economic growth and development of the EU; improving the quality of education and research, supporting the dissemination of innovative technologies and knowledge in the countries of EU. The implementation of such tasks makes it possible to improve the educational process, promote the development of economic and social change in European society. All tasks are implemented at the level of the European Union, national, regional and local levels on the basis of the principles of design, planning and controlling.

Let's pay attention to the tasks in the field of education and science in certain areas of the European strategy for economic development «Europe2020: a strategy for smart, sustainable and inclusive growth».

The task of the direction «Innovation Union» is the direction of research, development and innovation to solve modern problems of society (climate change, the rational use of energy and resources, demographic problems and health problems). The implementation of the goals and objectives is carried out in the following areas: the creation of a European space for research and innovation, the rational use of resources, health, production of organic products, land management, strengthening cooperation with Member States and EU regions, improving conditions for business and innovation; strengthening and developing EU policy instruments to support development and innovation; reforming the national and regional research system, introduction of cocreation of programs and increase of cooperation with other EU countries on questions of financing, guarantee of distribution of technologies across all EU; improvement of curricula of schools, universities, institutes in accordance with the principles of development of creative abilities, innovations and entrepreneurship.

The goal of the Youth Movement direction is to increase the international attractiveness of European higher education and improve the quality of education at all levels in the EU, to ensure the employment of young professionals, which consists in introducing and strengthening the program of freedom of movement, university studies; implementation of modernization of higher education within the framework of educational programs; entrepreneurship education through student and teacher mobility programs; support for nonformal learning; development and implementation of general principles of youth employment. At the national level, it is necessary to ensure: guarantees of sufficient investment in education at all levels; improving the effectiveness of openness and accessibility of educational systems through the creation of national qualification standards; improving labor market conditions through the adoption of guidelines, consultation, and training.

The aim of the European Digital Development Plan is to achieve sustainable economies and social benefits by creating a common EU digital market based on high-speed Internet, secured by a stable legislative framework; the spread of Internet access among EU citizens, the promotion, placement and use of modern network services (e-government, online health care, smart home).

The objective of the direction «Appropriate use of resources in Europe» are: mobilization of financial levers as a component of investment policy; completion of the construction of a single energy market and the introduction of a strategic plan for the use of energy resources, based on the idea of using renewable energy; approval and implementation of plans for the rational use of energy, implementation of projects for infrastructure changes.

The educational objectives of Industrial Policies for Globalization should be realized in the implementation of the intention to work with stakeholders to develop general principles of modern industrial policy. Important for the development of education and science are the development of measures to support industrial policy (reasonable regulation, a modern approach to public procurement, competition rules and standardization); supporting the internationalization of medium and small enterprises; supporting the use of technological and production methods that reduce energy consumption; increased competition in the EU economy, etc. (Europe 2020. Strategy for smart, sustainable and inclusive growth, 2010).

In addition, EU Member States and regions have developed comprehensive research and innovation strategies. This achieves five important objectives: a) focusing each country on 
the challenges and needs for knowledge-based innovation and development; b) focus on stimulating private sector investment in research and technological development; c) based on the competitive advantages of the region of each country with a focus on improving them; d) improving stakeholder access to participation and support for innovation and experimentation; e) based on factual data, use of monitoring indicators (Dombrovska, 2011; European approaches to assessing the quality of education).

Thus, the provisions of strategic documents show that education and science have become a determining factor in human development in a globalized world. Today they are an unalterable means of national self-affirmation and innovative development. The experience gained in the EU of economic development and implementation of educational programs is very promising for creative use in Ukrainian practice.

The strategic goal of the national policy of the EU countries in the field of education at the beginning of the XXI century, there are problems of purposeful influence on the conditions and prerequisites for the implementation of the rules of law, focusing the benefits of modernization educational activities during the transformation period, improving the entire education system and the mechanism for implementing the constitutional right to education.

Based on the analysis of scientific and documentary sources (Higher education in the XXI century, 1998; Memorandum of lifelong education of the European Union, 2000; Europe 2020; Luke, 2006; Petrova, 2015; Saiti, 2003), we have identified areas that have the greatest influence on the process of training specialists in education management in European education: direction to the methodological support of activities in the framework of European education; standardization of educational content, licensing, certification and accreditation of educational institutions, recognition of qualifications at the level of higher education; improving the education management system, decentralization and diversification in education.

We will reveal each of them in more detail.

1. Focus on methodological support of activities in the framework of European education. This group includes such basic UNESCO documents as the «Convention against Dis- crimination in Education», «Recommendations for the Development of Adult Education», «The Universal Right to Higher Education for the 21st Century» and others. All UNESCO documents are based on the principles and norms enshrined in the United Nations Organization Charter, the Universal Declaration of Human Rights, and other UN documents and contain specific regulations governing educational relations in any separate, relatively independent field of education, as well as consolidating effective mechanisms designed to ensure the implementation of these provisions in specific relationship.

The «Standard National Law on the Development of Tolerance» (2012) legally regulates legal relations in the field of tolerance in $\mathrm{Eu}$ ropean countries (the Standard National Law on the Development of Tolerance). The law regulates activities, including in the field of education, in the spirit of tolerance in society without weakening the ties that form society as a whole, fostering tolerance between different communities and groups, eradicating hatebased crime, condemning any manifestations of intolerance, based on prejudice, bigotry or prejudice, taking concrete measures to combat intolerance in order to eradicate racism.

Of practical interest is the «World Declaration on Higher Education for the XXI Century: Approaches and Practices» (1998) (Higher Education in the XXI century, 1998). This document positively assesses the process of education development in the second half of the twentieth century and identifies the main activities designed to maintain and increase the success of education in the new century. The paper emphasizes the need to move from learning focused on cognitive learning to learning to develop skills and abilities related to communication, creative and critical analysis, independent thinking and teamwork in a multicultural context. At the same time, the Declaration emphasizes that a specialist with higher education should not only be a professional, but also have a sense of social responsibility, be an active member of modern civil society and promote the principles of equality and justice.

This group of documents at the beginning of the XXI century includes the report of the World Bank on the world development «Change in the nature of work» (2019) (Development Report (WDR) 2019 :). It is noted that the level of professional skills in demand 
in the labor market is changing rapidly, which creates both new opportunities and new risks. There is ample evidence that without human capital development, countries will not be able to achieve sustainable economic growth for the benefit of all segments of the population, nor prepare a contingent of workers who will be ready to take the jobs of the future that require advanced training or compete effectively in the world economy.

2. Standardization of the content of education, licensing, certification and accreditation of educational institutions for the recognition of qualifications related to higher education. The proposal to develop a single, general convention on the improvement of European conventions on higher education, as well as the UNESCO Convention on the Recognition of Courses, diplomas of higher education and academic degrees in the countries of the European region, was presented at the 16th session of the Standing Conference on University Problems and approved by the twentyseventh session of the General Conference of UNESCO.

The Convention on the Recognition of Qualifications concerning Higher Education in the European Region, adopted in Lisbon (1997) (Convention on the Recognition of Qualifications, 1997), is a fundamental document of the legal framework for international educational cooperation in more than 50 countries of the world. The Convention brings together a wide variety of educational documents, which are referred to in it as "qualifications»,

- School certificates and diplomas of primary vocational education, all diplomas of complete general secondary, higher and postgraduate vocational education, including doctoral diplomas; academic certificates of study periods.

The concept of a new model of European education is contained in the conclusions of the Lisbon Summit on EU education policy, reflected in the «Memorandum of Continuing Education of the European Union» (Memorandum of Continuing Education of the European Union, 2000). The Memorandum states that the successful transition to a knowledge-based economy and society must be accompanied by a process of continuing education (lifelong learning). In addition to formal education, which ends with the receipt of a generally accepted diploma or certificate, around which the educational policy of any state is formed, the concept of continuing education includes two other types of educational activities, namely: non-formal education (usually not accompanied by the issuance of a state standard document, obtained in educational institutions or public organizations, clubs and circles, as well as during individual lessons with a tutor or coach) and informal education. Within the framework of this concept, non-formal and informal types of education are included in the general learning process.

The provision of continuing education is based on the following principles: new basic knowledge and skills for all, which includes the implementation of general continuing access to education in order to obtain and update the skills necessary for inclusion in the information society (computer literacy, foreign languages, technological culture, entrepreneurship and social skills - self-confidence, responsibility, etc.); increase investment in human resources; innovative teaching and learning methods; a new system of assessment of education, taking into account all types of education: formal, non-formal and informal; development of mentoring and counseling.

3. Improving the education management system, decentralization and diversification in education. In the context of our study, the provisions of the report «School Autonomy in Europe: Policy and Implementation», announced by J. Figel, Commissioner for Education, Training, Culture and Youth of the European Commission for Education and Culture in 2008, are relevant, which defines the concept and content of school autonomy, the powers of decision-making bodies, the areas of competence of authorized persons, the role and composition of governing bodies in the school, models of responsibility for decisions, etc. School autonomy - practiced as independence from the general policy of the state and the renewal of decentralization / deconcentration of administrative powers in the field of education, which should be an objective or even the main principle of school management and educational policy in the sense that educational institutions should be autonomous in order to ensure freedom of teaching in order to improve the quality of education. (Autonomie škol in Europe, 2008, pp. 46-47).

The document of the European Commission's Directorate-General for Education and Culture «Administration and Management in Higher Education: Principles, Structure, Fund- 
ing and Academics» (2009) sets out strategic priorities in funding, staffing policy for academics, governance structure in higher education, models state funding of education, issues of autonomy in the use of income from payment for educational services, problems of social partnership in education, etc. Unions and associations of universities across Europe, in the context of educational governance reform, should address this problem through the organization of advanced training programs for staff, academics and others, offering training, courses and seminars on university governance.

With the reform of the institutional structure of the management of educational institutions, the role of leadership has also changed. Its task is to ensure a balance in the division of powers within the institution and, above all, responsibility for all activities of the educational institution. Scientific skills are still the main qualification requirement for the position of university head. The report states that in order to acquire additional qualification skills to become a head of an educational institution, knowledge of personnel policy and management skills is required, as the scientific and pedagogical competence of an employee does not guarantee that he is a leader, diplomat and strategist (Správa a řízení vysokého školství v Evropě,2009, c. 105-106).

The European Strategy Europe 2020 (2010), as a strategy for smart, sustainable and inclusive growth in the EU, contains a Plan for New Skills and Jobs (Europe 2020). The purpose of the Plan is to create the necessary conditions for improving the labor market to increase employment and guarantee the stability of society. By stimulating Europeans with new opportunities through their knowledge and skills, the EU is targeting the future workforce to adapt to changing labor market conditions, leading to lower unemployment and higher worker productivity.

International and European regulations as part of national legislation, as well as resolu- tions, conventions, which have the status of recommendation documents, significantly affect the formation of the content of training for education management in European countries: determine the methodological guidelines for the formation of basic concepts of management in education, provide the legal basis for fundamental, humanities and vocational disciplines, contribute to the design and modeling of strategies for the development of education and training, taking into account socioeconomic, political, technological changes for the spiritual and cultural development of society. For Ukrainian education, it is important to adhere to democratic principles in the field of governance, to fully ensure the rights and freedoms of the subjects of the educational process, to take into account the cultural characteristics of all peoples and the peculiarities of preparing a person for life in an open multicultural society, to integrate the national idea with general civilization spiritual orientations.

Human capital development is at the heart of the global development strategy. Protecting and investing in people is one of the three main areas of action to achieve humanity's goal of eradicating poverty by 2030 and accelerating shared prosperity in all countries. This work is an integral part of efforts to promote sustainable economic growth for the benefit of all segments of the population and increase the resilience of all countries.

Conclusions. On the basis of the foregoing, it can be argued that in order to realize the development goals of an educational institution, society needs a specialist in educational management of high culture, able to reflect, to correct their own actions and deeds, able not only to speak but also to listen, understand others. All this is connected with spirituality, with the knowledge of the values of the special, the other, with the attitude to understanding, with the desire to help everyone, to protect the weak, the study of which may be prospects for further research.

\section{REFERENCES}

Vy`sshee obrazovanie v XXI v. (1998): podkhody`i prakticheskie mery`. Ot analiza k mobilizuyushhim princzipam [nachalo publikaczii referata Rabochego dokumenta Vsemirnoj konferenczii YuNESKO «Vy`sshee obrazovanie v XXI v.: podkhody` i prakticheskie mery`» (Parizh, 5-9 oktyabrya 1998 g.). Al'ma Mater Vestnik vy'sshej shkoly',11, 3-9.

Dombrovska, S. (2011). Yakist osvity yak odna iz zaporuk vdaloho derzhavnoho reformuvannia vyshchoi shkoly Ukrainy. Aktualni problemy derzhavnoho upravlinnia, 1 (39). URL: http://www.kbuapa.kharkov.ua/e-book/apdu/2011-1/index.html.

Ievropeiski pidkhody do otsinky yakosti osvity. URL: http: //www.ibe.unesco.org/cops/russian/EU 
Konventsiia pro borotbu z dyskryminatsiieiu v haluzi osvity. (1997). URL: http://zakon4.rada.gov.ua/.

Lukianova, L. B. (2016). Kontseptsiia rozvytku osvity doroslykh v Ukraini (2 he vyd.). Kyiv: TOV «DKSTsentr».

Memorandum neprery`vnogo obrazovaniya Evropejskogo Soyuza. (2000). URL: www.znanie.org/docs/ memorandum.html.

Rekomendatsiia IeS Yevropeiskoho Parlamentu ta Rady (IeS): Pro osnovni kompetentsii dlia navchannia protiahom usoho zhyttia (2006). URL: https://zakon.rada.gov.ua/laws/show/994 975\#Text.

Typovyi natsionalnyi zakon pro rozvytok tolerantnosti. (nd). URL: $\underline{\text { http://moscow.pink. }}$

Autonomie škol v Evropě: politická a realizační opatření Eurydice. (2008). Brusel: Eurydice. https://op.europa.eu/en/publication-detail/-/publication/102bb131

Europe 2020. Strategy for smart, sustainable and inclusive growth. URL: http://ec.europa.eu/

Luke, A., \& Hogan, D. (2006). Redesigning what counts as evidence in educational policy: The Singapore model. World Handbook of Education (pp. 170-184). London: Routledge.

Petrova, D., \& Panko, M. (2015). European Policies and Strategies 2020 - administration, industry, education in Bulgaria. Scientific Bulletin of Mukachevo State University. Economy, 1, 2(4), 189-192.

Reimagining Life Skills and Citizenship Education in the Middle East and North Africa. A Four-Dimensional and Systems Approach to 21st Century Skills. Conceptual and Programmatic Framework. Executive summary. United Nations Children's Fund. www.lsce-mena.org.

Saiti, A. (2003). Evidence from Greek secondary education. Management in Education, 17(2), 8-34.

Správa a řízení vysokého školství v Evropě, Principy, struktury, financování a akademičtí pracovníci Ústav pro informace ve vzdělávání, 2009. URL: https://op.europa.eu/cs/publication-detail//publication/f4a537e6-0e90-413b-98b1-e9bf9b1eb90c/language-cs.

Strategie vzdělávací politiky ČR do roku 2030+. URL: https://www.msmt.cz/ vzdelavani/skolstvi-vcr/strategie-2030.

The World Development Report (WDR): 2019. URL: https://www.worldbank.org/en/ publication/wdr2019.

Оксана Товканець, доктор педагогічних наук, доцент, професор кафедри загальної педагогіки та педагогіки вищої школи ДВНЗ «Ужгородський національний університет».

Oksana Tovkanets, Doctor of Sciences in Pedagogy, Associate Professor, Professor of Department of General Pedagogy and Higher School Pedagogy, Uzhhorod National University.

E-mail: oksana.tovkanets@uzhnu.edu.ua

ORCID ID 0000-0003-4438-0167 